Article

\title{
Impact of Furfural on Rapid Ethanol Production Using a Membrane Bioreactor
}

\author{
Päivi Ylitervo ${ }^{1,2, *}$, Carl Johan Franzén ${ }^{2}$ and Mohammad J. Taherzadeh ${ }^{1}$
}

1 School of Engineering, University of Borås, 50190 Borås, Sweden;

E-Mail: mohammad.taherzadeh@hb.se

2 Industrial Biotechnology, Chalmers University of Technology, 41296 Göteborg, Sweden;

E-Mail: franzen@chalmers.se

* Author to whom correspondence should be addressed; E-Mail: paivi.ylitervo@hb.se;

Tel.: +46-33-435-4643; Fax: +46-33-435-4008.

Received: 9 January 2013; in revised form: 26 February 2013 / Accepted: 1 March 2013 /

Published: 11 March 2013

Abstract: A membrane bioreactor was developed to counteract the inhibition effect of furfural in ethanol production. Furfural, a major inhibitor in lignocellulosic hydrolyzates, is a highly toxic substance which is formed from pentose sugars released during the acidic degradation of lignocellulosic materials. Continuous cultivations with complete cell retention were performed at a high dilution rate of $0.5 \mathrm{~h}^{-1}$. Furfural was added directly into the bioreactor by pulse injection or by addition into the feed medium to obtain furfural concentrations ranging from 0.1 to $21.8 \mathrm{~g} \mathrm{~L}^{-1}$. At all pulse injections of furfural, the yeast was able to convert the furfural very rapidly by in situ detoxification. When injecting $21.8 \mathrm{~g} \mathrm{~L}^{-1}$ furfural to the cultivation, the yeast converted it by a specific conversion rate of $0.35 \mathrm{~g} \mathrm{~g}^{-1} \mathrm{~h}^{-1}$. At high cell density, Saccharomyces cerevisiae could tolerate very high furfural levels without major changes in the ethanol production. During the continuous cultures when up to $17.0 \mathrm{~g} \mathrm{~L}^{-1}$ furfural was added to the inlet medium, the yeast successfully produced ethanol, whereas an increase of furfural to 18.6 and $20.6 \mathrm{~g} \mathrm{~L}^{-1}$ resulted in a rapidly decreasing ethanol production and accumulation of sugars in the permeate. This study show that continuous ethanol fermentations by total cell retention in a membrane bioreactor has a high furfural tolerance and can conduct rapid in situ detoxification of medium containing high furfural concentrations. 
Keywords: ethanol; Saccharomyces cerevisiae; membrane bioreactor; cross-flow filtration; furfural conversion kinetics

\section{Introduction}

Lignocellulosic material can be converted to fermentable sugars by acid or enzymatic hydrolysis [1,2]. Acid hydrolysis and pretreatments are efficient methods for opening up the crystalline structure of lignocellulose and hydrolyze both hemicelluloses and cellulose. However, several toxic substances are either released from the lignocellulosic structure or formed during the degradation process. These substances can severely inhibit the metabolism of the fermenting microorganism $[3,4]$. Three major groups of inhibitors are present in the hydrolyzate: aliphatic acids, phenolic compounds and furan aldehydes [5]. The furan aldehydes, furfural and 5-hydroxymethfural (HMF) are produced as primary degradation products from pentoses and hexoses during the hydrolysis when strong acids are present. As a result, it is very difficult to completely avoid the formation of furfural and HMF in a chemical hydrolysis process. Furfural is recognized as one of the most inhibiting substances in the hydrolyzate $[5,6]$. Consequently, several studies have investigated the effects of furfural on fermentation and yeast growth [7-9]. A study made with several different hydrolyzates showed a clear relationship between the sum of furfural and HMF concentrations and the fermentation rate [10]. The use of hydrolyzates in continuous cultivations has only been successful at low dilution rates so far $[11,12]$.

Baker's yeast is the most common organism used to convert the sugars to ethanol. The yeast is able to convert furfural to less inhibitory compounds. Under anaerobic conditions, furfural is mainly converted to furfuryl alcohol [7]. One suggestion is therefore to use a high-level yeast inoculum as a way to alleviate the toxic effect hydrolyzates has on the yeast, since the yeast is able to take up and convert furfural $[13,14]$. Additionally, a severely inhibiting hydrolyzate can be fermented much easier by continuous or fed-batch cultivations than by batch cultivations, as long as the dilution rate is adapted to the cells' capacity to convert the inhibitors [11,15]. One way to increase the inhibitor conversion capacity during continuous cultivation is to retain the cells in order to achieve higher concentration of the cells in the bioreactor.

Membrane bioreactors are now well developed for the aerobic treatment of wastewater and also for anaerobic conversion to biogas [16]. In these reactors, cells are retained using membranes in order to obtain high cell concentrations and speed up the process. In addition, very high cell concentrations have been reported when combining membrane-based separation methods with continuous cultivations in a bioreactor. For instance Lafforgue et al. [17] reached a yeast concentration of $345 \mathrm{~g} \mathrm{~L}^{-1}$ with a cell viability of above $75 \%$ in a continuous cultivation by applying total cell recycling at a dilution rate of $0.5 \mathrm{~h}^{-1}$. Lee and Chang obtained a cell concentration of $210 \mathrm{~g} \mathrm{~L}^{-1}$ and also confirmed they were able to control the cell mass inside the bioreactor by adjusting the cell bleeding rate [18]. In a contemporary study made in a two stage bioreactor coupled to an ultrafiltration unit a very high ethanol productivity of up to $41 \mathrm{~g} \mathrm{~L}^{-1} \mathrm{~h}^{-1}$ was reached at a biomass concentration of $157 \mathrm{~g} \mathrm{~L}^{-1}$ [19].

The aim of this study was to elucidate the furfural conversion and effects of furfural on the ethanol production during continuous cultivations of Saccharomyces cerevisiae at high cell density and a rapid 
dilution rate of $0.5 \mathrm{~h}^{-1}$. A high yeast density was achieved by coupling the bioreactor to an external cross-flow membrane filtration unit by which spent medium could be withdrawn. The effect of furfural was studied both by pulse addition of furfural into the bioreactor and by addition of furfural in the inlet medium.

\section{Experimental Section}

\subsection{Yeast Strain and Medium}

Saccharomyces cerevisiae CBS 8066, obtained from Centraalbureau voor Schimmelcultures (Delft, The Netherlands) was used throughout this investigation. The strain was maintained on YPD agar plates containing 1\% yeast extract (Scharlau, Sentmenat, Spain), 2\% soy peptone (Fluka, Steinheim, Germany), 2\% D-glucose (Fisher Scientific, Leicestershire, UK) and 2\% agar (Scharlau Sentmenat, Spain), and stored at $4{ }^{\circ} \mathrm{C}$. The culture and inoculum media contained $1 \mathrm{~g} \mathrm{~L}^{-1}$ yeast extract, $5 \mathrm{~g} \mathrm{~L}^{-1}$ $\mathrm{KH}_{2} \mathrm{PO}_{4}, 2 \mathrm{~g} \mathrm{~L}^{-1}\left(\mathrm{NH}_{4}\right)_{2} \mathrm{SO}_{4}$ [17], and $100 \mathrm{~g} \mathrm{~L}^{-1}$ sucrose (from Beta vulgaris, Dan Sukker, Örtofta, Sweden) as carbon source. In order to avoid foaming, $0.1 \mathrm{~mL} \mathrm{~L}^{-1}$ silicon antifoam 426R (VWR International AB, Paris, France) was added to the medium. The sugar and salt solutions were autoclaved separately.

\subsection{Cross-Flow Membrane}

The bioreactor was connected to an external tubular cross-flow membrane filtration unit (dizzer ${ }^{\circledR}$ LAB 1.5 MB 0.1 (inge Gmbh, Greifenberg, Germany), surface of $0.1 \mathrm{~m}^{2}$, pore size $\sim 0.02 \mu \mathrm{m}$ ) in order to remove spent medium while retaining the yeast cells inside the bioreactor. Figure 1 illustrates the bioreactor setup used for continuous cultures with cell retention. Culture medium was fed continuously into the bioreactor at a dilution rate of $0.5 \mathrm{~h}^{-1}$. To provide sufficient filtration the yeast suspension was continuously circulated through the cross-flow unit at $\sim 0.5 \mathrm{~L} \mathrm{~min}^{-1}$. Before each run, the membrane unit was cleaned with $500 \mathrm{mg} \mathrm{L}^{-1} \mathrm{H}_{2} \mathrm{O}_{2}$ solution, sterilized with sodium hypochlorite solution $\left(100 \mathrm{mg} \mathrm{L}^{-1}\right.$ active chlorine) and rinsed with sterile water.

Figure 1. Schematic design of the bioreactor setup used during continuous cultures with yeast retention, bioreactor (1) and membrane module (2).

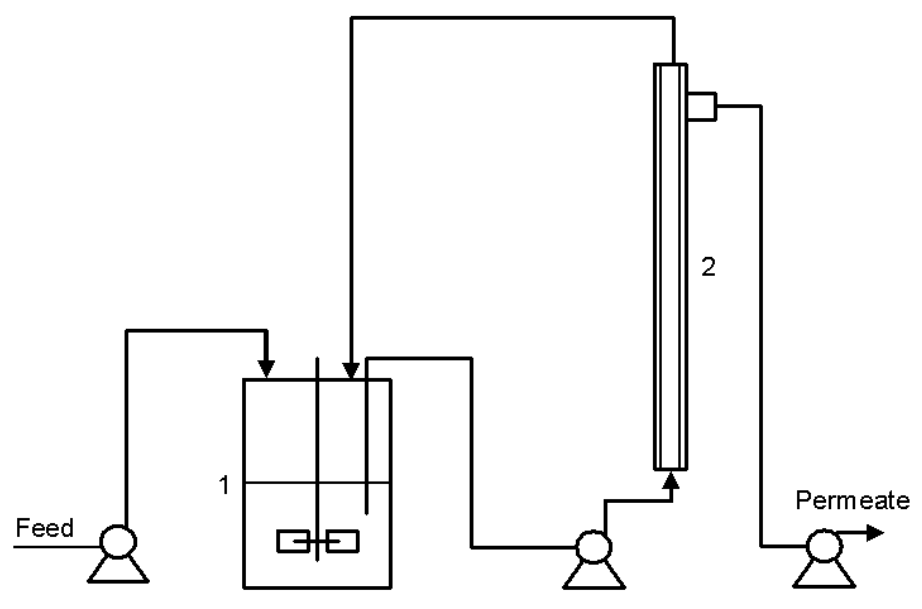


A harvesting pump was connected to a level controller to remove culture broth with the cross-flow filter to maintain the liquid volume constant at $1 \mathrm{~L}$. Stopping the permeate pumping periodically will also relax the membrane and let the flow through the tubular membrane eliminate cake formation and remove fouling substances [16].

\subsection{Cultivation Conditions}

Anaerobic continuous cultivations were performed in a $2.5 \mathrm{~L}^{\text {Biostat }}{ }^{\circledR}$ A bioreactor (B. Braun Biotech International, Metsungen, Germany) using the cultivation medium described above. The total liquid volume in the bioreactor, cross-flow filter and recirculation loop was $1.0 \mathrm{~L}$, of which the volume in the filter and recirculation loop corresponded to $0.2 \mathrm{~L}$. The bioreactor working conditions were set to $30{ }^{\circ} \mathrm{C}$, a stirring rate of $300 \mathrm{rpm}$, a dilution rate of $0.5 \mathrm{~h}^{-1}$ in continuous cultivations and $\mathrm{pH} 5.00$ $( \pm 0.05)$, set by addition of $2 \mathrm{M} \mathrm{NaOH}$. During cultivations, the bioreactor was purged with a

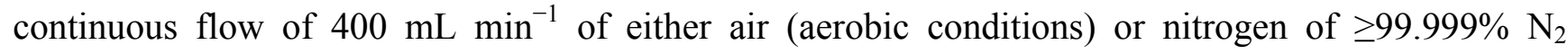
(anaerobic conditions). The oxygen content in the nitrogen gas (ADR class 2, 1 (a), AGA Sweden, Göteborg, Sweden) was less than 5 ppm.

Yeast inoculum cultures were grown in cotton-plugged Erlenmeyer flasks, containing $100 \mathrm{~mL}$ of culture medium, in a water bath at $30^{\circ} \mathrm{C}$ and $130 \mathrm{rpm}$ for $24 \mathrm{~h}$. The cultivation inside the bioreactor was started with $1 \mathrm{~L}$ cultivation medium, inoculated with $10 \mathrm{~mL}$ of yeast culture, and aerobically cultivated for $24 \mathrm{~h}$ in batch process. Then, substrate medium was continuously fed to the bioreactor at flow rate $0.5 \mathrm{~L} \mathrm{~h}^{-1}$. The outlet passed through a cross-flow membrane unit. The yeast was grown aerobically in the bioreactor until a high yeast dry weigh was reached, around $60 \mathrm{~g} \mathrm{~L}^{-1}$ for pulse injection experiments and around $120 \mathrm{~g} \mathrm{~L}^{-1}$ for continuous furfural fed experiments. The cultivation condition was changed to anaerobic mode $12 \mathrm{~h}$ before any furfural addition.

Furfural (99\%, Sigma Aldrich, St. Louis, USA) was either added directly into the bioreactor by pulse injection or continuously fed together with the substrate. Two separate continuous cultivations were performed for both pulse injection and continuous furfural addition to the feed medium. From here on cultivation A will be abbreviated with (A) and cultivation B with (B). Peristaltic pumps (Watson-Marlow, Falmouth, UK) were used to both feed medium into the bioreactor and remove fermented broth after passing through the cross-flow membrane. Samples from the cultivation were taken at $0,0.25,0.5,1,1.5,2,3,4 \mathrm{~h}$ after pulse injection of furfural, whereas when furfural was continuously fed to the bioreactor, samples were taken at $0,1,2,4,6,8,12$, and $24 \mathrm{~h}$ after every change of the inlet furfural concentration. During furfural pulse injections samples were taken both from the cultivation broth and the filter permeate. Furfural levels were determined from the cultivation broth in order to note the fast changes in furfural concentrations. The sugar and metabolite concentrations were determined from the permeate.

\subsection{Determination of Yeast Viability and Dry Weight Concentration}

The yeast viability was determined by colony forming units by diluting the yeast suspension sampled from the bioreactor appropriately with $0.1 \%$ peptone and $0.9 \% \mathrm{NaCl}$ solution. For each dilution, triplicate samples of $100 \mu \mathrm{L}$ were spread on YPD plates. After approximately $48 \mathrm{~h}$ of incubation at $30{ }^{\circ} \mathrm{C}$, the numbers of colonies were determined. During continuous cultivations with 
pulse injections of furfural, the viability was assayed both before injection and $4 \mathrm{~h}$ after the injection. For cultivations with continuous addition of furfural, the viability was measured both before adding furfural and after every $24 \mathrm{~h}$.

Dry weight concentration of cells was determined by removing $1.0 \mathrm{~mL}$ yeast suspension from the bioreactor, the samples were centrifuged $(9,600 \times \mathrm{g}, 5 \mathrm{~min})$ and washed three times with water. The samples were dried in pre-weighed glass tubes at $105{ }^{\circ} \mathrm{C}$ for $24 \mathrm{~h}$ and weighed after temperature equilibration in a desiccator.

\subsection{Sugar and Metabolite Analyses}

Samples withdrawn from the cultivations were centrifuged $(9,600 \times \mathrm{g}, 5 \mathrm{~min})$ and the supernatant was decanted into new tubes and stored at $-20^{\circ} \mathrm{C}$ until analysis. Metabolite and furfural concentrations were determined by HPLC (Waters 2695, Waters Corporation, Milford, Mass. USA) using an ion-exchange column (Aminex HPX-87H, Bio-Rad, Hercules, CA USA) at $60{ }^{\circ} \mathrm{C}$ with $5 \mathrm{mM} \mathrm{H}_{2} \mathrm{SO}_{4}$ as eluent. The eluent flow was kept at $0.6 \mathrm{~mL} \mathrm{~min}^{-1}$ and a refractive index detector (Waters 2410) and a UV absorbance detector (Waters 2486) were used in series. Furfural concentrations were determined from the UV chromatogram at $210 \mathrm{~nm}$, whereas the other metabolites were analyzed by the refractive index detector. The lower sugar concentrations during pulse injections were analyzed by an Aminex HPX-87H column at $30{ }^{\circ} \mathrm{C}$ with $5 \mathrm{mM} \mathrm{H}_{2} \mathrm{SO}_{4}$ at an eluent flow of $0.6 \mathrm{~mL} \mathrm{~min}{ }^{-1}$. The higher sugar concentrations during continuous furfural addition was analyzed by an Aminex HPX-87P column (Bio-Rad, Hercules, CA USA) at $85{ }^{\circ} \mathrm{C}$, with ultrapure water as elutent at a flow rate $0.6 \mathrm{~mL} \mathrm{~min}{ }^{-1}$. The sugar concentrations were determined by the refractive index detector.

\section{Results and Discussion}

\subsection{The Cross Flow Membrane}

Cross-flow filtration is ideal for industrial-scale separation, purification, concentration and clarification processes in the biological, medical, food, dairy, beverage and pharmaceutical industries. Membrane fouling is the main difficulty, which can be dealt with by applying high cross-flow velocities and membrane cleaning [20,21]. The cross flow membrane used during this study was run with no fouling problems during one entire week without any chemical cleaning. Physical cleaning by relaxing the membrane was employed in order to avoid fouling. During the entire study, the permeate from the cross-flow unit was entirely transparent and free of suspended yeast.

One observation made during the cultivations was that the tubular cross-flow membrane was affected by the furfural concentration in the broth. As the furfural concentration was increased to $10 \mathrm{~g} \mathrm{~L}^{-1}$ and above, the tubular membranes started to elongate and twist inside the module. However, no tubular membranes broke during any of the cultivations and the permeate from the filter was always transparent and essentially free from yeast. As medium containing less furfural was supplied to the system, the tubular membrane retained its original shape. Because of the problem with the elongation of the membranes and the risk of blocking the $0.9 \mathrm{~mm}$ diameter tubular holes, it was decided not to increase the furfural to more than $20.6 \mathrm{~g} \mathrm{~L}^{-1}$. 
The membranes used in the module applied performed ultrafiltration and had a pore size of about $0.02 \mu \mathrm{m}$. An ultrafiltration module was applied since some studies have shown that ultrafiltration modules have a lower fouling rate than microfiltration modules [22,23].

\subsection{Anaerobic Pulse Addition Experiments}

The anaerobic conversion of furfural and its effect on ethanol production was studied by pulse injection of furfural to a continuous cultivation of yeast at high biomass concentration. By injecting furfural directly inside the bioreactor, the furfural concentration could be raised very quickly in the broth, and the effect on the cultivation could be evaluated. Each day, the cultivation was exposed to two pulse injections of different amounts of furfural, once in the morning and once four hours after the first injection. Two separate cultivations were performed and the results for both cultivations are summarized in Figure 2. The product yields and carbon balance for both cultivations are presented in Table 1. During pulse injections of furfural the ethanol yield on sucrose $\left(\mathrm{Y}_{\mathrm{p} / \mathrm{s}}\right)$ was stable, and had an average value of $0.49 \pm 0.02$. Hence, the production of ethanol was not influenced to any larger extent by the injection of furfural.

Table 1. Product yields and carbon balance during anaerobic continuous cultivations with either pulse injection or continuous furfural addition. The indicated furfural concentration is either the amount of furfural pulse injected to the cultivation or the level of furfural in the feed medium.

\begin{tabular}{|c|c|c|c|c|c|c|c|}
\hline \multicolumn{4}{|c|}{ Furfural pulse injections } & \multicolumn{4}{|c|}{ Furfural in feed medium } \\
\hline $\begin{array}{c}\text { Furfural } \\
{\left[\mathrm{g} \mathrm{L}^{-1}\right]}\end{array}$ & $Y_{p / s}{ }^{c}$ & $\mathrm{Y}_{\mathrm{gly} / \mathrm{s}}^{\mathrm{c}}$ & $\begin{array}{c}\text { Carbon } \\
\text { balance }^{\mathrm{e}}\end{array}$ & $\begin{array}{c}\text { Furfural } \\
{\left[\mathrm{g} \mathrm{L}^{-1}\right]}\end{array}$ & $\mathrm{Y}_{\mathrm{p} / \mathrm{s}}{ }^{\mathrm{d}}$ & $\mathrm{Y}_{\mathrm{gly} / \mathrm{s}}{ }^{\mathrm{d}}$ & $\begin{array}{c}\text { Carbon } \\
\text { balance }^{\mathrm{e}}\end{array}$ \\
\hline $0.1^{\mathrm{b}}$ & 0.45 & 0.041 & 0.93 & $4.1^{\mathrm{b}}$ & 0.52 & 0.018 & $0.99 \pm 0.02$ \\
\hline $0.5^{b}$ & 0.45 & 0.042 & 0.96 & $5.7^{\mathrm{b}}$ & 0.53 & 0.013 & $0.99 \pm 0.02$ \\
\hline $0.8 \pm 0.1^{\mathrm{a}, \mathrm{b}}$ & $0.48 \pm 0.04$ & $0.039 \pm 0.004$ & $1.01 \pm 0.05$ & $6.7^{\mathrm{a}}$ & 0.51 & 0.015 & $1.03 \pm 0.06$ \\
\hline $1.5 \pm 0.0^{\mathrm{a}, \mathrm{b}}$ & $0.48 \pm 0.04$ & $0.037 \pm 0.003$ & $0.98 \pm 0.00$ & $7.8^{b}$ & 0.50 & 0.013 & $0.93 \pm 0.01$ \\
\hline $3.9 \pm 0.2^{\mathrm{a}, \mathrm{b}}$ & $0.49 \pm 0.04$ & $0.039 \pm 0.004$ & $0.99 \pm 0.02$ & $9.0^{b}$ & 0.53 & 0.011 & $1.00 \pm 0.01$ \\
\hline $6.1 \pm 0.1^{\mathrm{a}, \mathrm{b}}$ & $0.49 \pm 0.03$ & $0.031 \pm 0.003$ & $0.98 \pm 0.02$ & $9.6^{\mathrm{a}}$ & 0.53 & 0.009 & $1.01 \pm 0.05$ \\
\hline $7.8 \pm 0.1^{\mathrm{a}, \mathrm{b}}$ & $0.50 \pm 0.04$ & $0.036 \pm 0.002$ & $1.00 \pm 0.00$ & $14.4^{b}$ & 0.50 & 0.013 & $0.90 \pm 0.04$ \\
\hline $10.3 \pm 0.0^{\mathrm{a}, \mathrm{b}}$ & $0.51 \pm 0.03$ & $0.026 \pm 0.007$ & $1.01 \pm 0.01$ & $17.0^{\mathrm{a}}$ & 0.53 & 0.010 & $1.02 \pm 0.03$ \\
\hline $15.6^{\mathrm{a}}$ & 0.52 & 0.036 & 0.95 & $18.6^{\mathrm{b}}$ & 0.30 & 0.021 & $0.63 \pm 0.23$ \\
\hline $21.8^{\mathrm{a}}$ & 0.49 & 0.026 & 0.90 & $20.6^{\mathrm{a}}$ & 0.19 & 0.017 & $0.79 \pm 0.21$ \\
\hline
\end{tabular}

${ }^{\mathrm{a}}$ Cultivation A; ${ }^{\mathrm{b}}$ Cultivation $\mathrm{B} ;{ }^{\mathrm{c}}$ Yields calculated $1 \mathrm{~h}$ after pulse injection of the indicated amount of furfural; ${ }^{\mathrm{d}}$ Yields calculated at steady state after $24 \mathrm{~h}$ of furfural addition of the indicated concentration; ${ }^{\mathrm{e}}$ Average carbon balances during $24 \mathrm{~h}$ of furfural addition of the indicated concentration. Standard deviation shows the variation during $24 \mathrm{~h}$. Carbon balance was calculated based on sucrose consumption and production of biomass, ethanol, glycerol and carbon dioxide. Formation of carbon dioxide was calculated from the ethanol production; $\mathrm{Y}_{\mathrm{p} / \mathrm{s}}=$ ethanol yield $(\mathrm{g} / \mathrm{g}) ; \mathrm{Y}_{\mathrm{gly} / \mathrm{s}}=$ glycerol yield $(\mathrm{g} / \mathrm{g})$. All yields are calculated based on the sum of the consumed glucose and sucrose.

At the lower furfural additions of 0.8 and $1.5 \mathrm{~g} \mathrm{~L}^{-1}$, ethanol and glycerol concentrations in the broth decreased less than $10 \%$. However, as larger amounts of furfural were injected to the cultivation, ethanol and glycerol concentration decreased up to around $20 \%$ and $60 \%$. Ethanol and glycerol production rates recovered after the furfural had been converted or eluted from the cultivation broth. A faster recovery occurred in the ethanol production rate compared to the glycerol production rate. 
Furfural conversion has earlier been shown to compensate for the production of glycerol [8]. Under anaerobic conditions, S. cerevisiae produces glycerol in order to re-oxidize the surplus cytosolic NADH in order to maintain the redox balance in the cell. As the reduction of furfural consumes $\mathrm{NADH}$, it prevents the formation of the same molar amount of glycerol. This will therefore lower the concentration of glycerol while the furfural is converted. The reduced glycerol production was clearly observed, especially when large amounts of furfural were added (Figure 2). However, after furfural was depleted from the cultivation broth, the glycerol production slowly increased again.

Figure 2. Concentrations of sucrose, glucose, ethanol, glycerol, and furfural during two anaerobic continuous cultivations with pulse injection of furfural (A and B). Each pulse injection of furfural is indicated by arrows. The gridlines denote each $12 \mathrm{~h}$ period in the continuous cultivation.
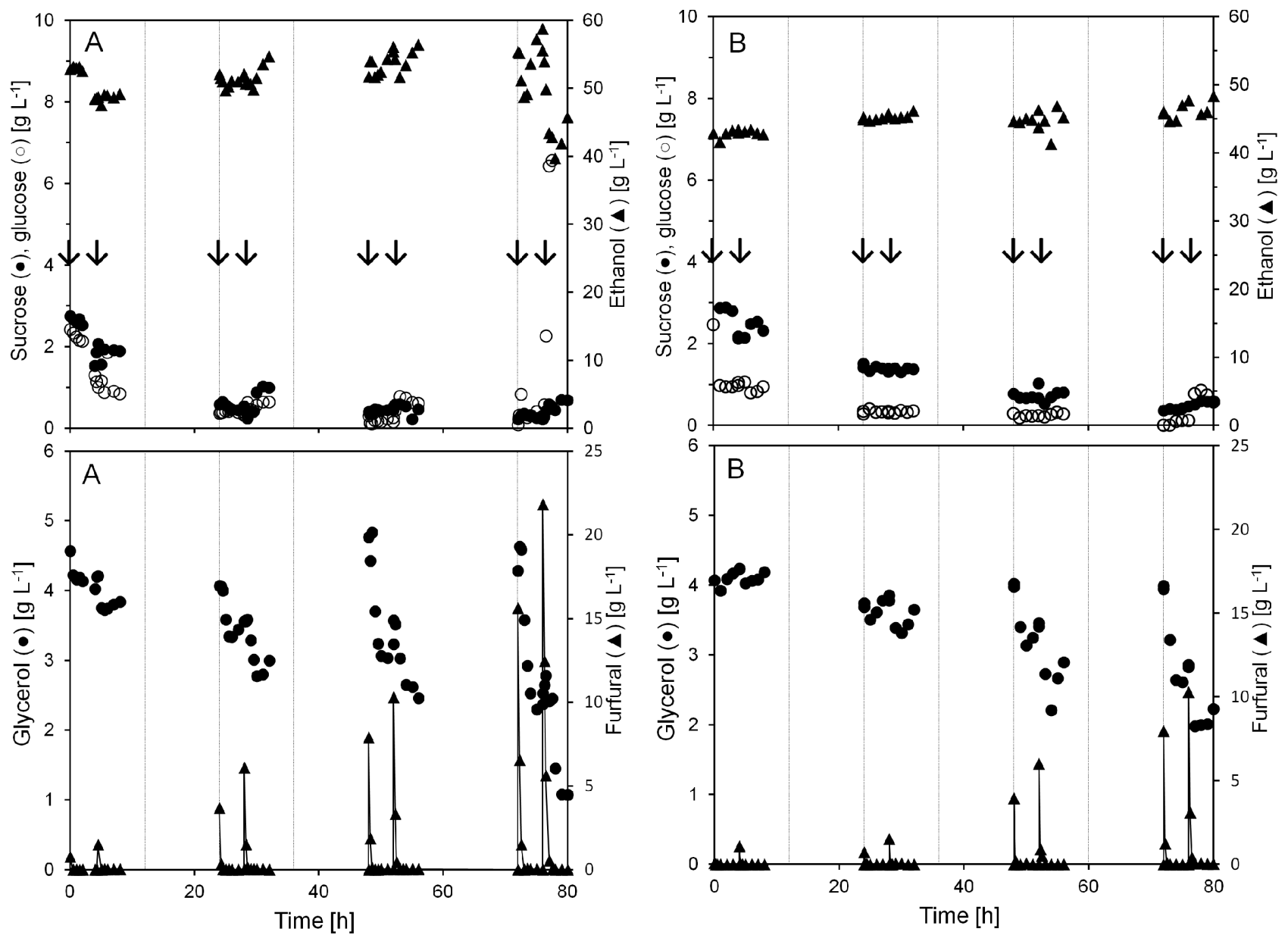

Pulse injection of 15.6 and $21.8 \mathrm{~g} \mathrm{~L}^{-1}$ furfural after $72 \mathrm{~h}$ in cultivation A caused the ethanol concentration to decline from 55 to below $40 \mathrm{~g} \mathrm{~L}^{-1}$ and the glycerol from $4.6 \mathrm{~g} \mathrm{~L}^{-1}$ to $1 \mathrm{~g} \mathrm{~L}^{-1}$. At the same time the glucose level rose from almost 0 to above $10 \mathrm{~g} \mathrm{~L}^{-1}$. Nevertheless, furfural conversion started immediately after the injection and at all the different pulse additions the furfural was gone from the cultivation broth within $1 \mathrm{~h}$ after the addition.

When furfural was injected to the culture in the current work, the yeast dry weight in the bioreactor was about $60 \mathrm{~g} \mathrm{~L}^{-1}$. After $72 \mathrm{~h}$ of cultivation it had doubled to approximately $120 \mathrm{~g} \mathrm{~L}^{-1}$ (Figure 3). In 
addition, the viability of the yeast was stable at around $1.5 \times 10^{9} \mathrm{CFU} \mathrm{mL}{ }^{-1}$. This shows that the pulse injection of furfural did not severely affect the yeast viability in the cultivation until $72 \mathrm{~h}$. After $76 \mathrm{~h}$ when furfural addition was increased to $21.8 \mathrm{~g} \mathrm{~L}^{-1}(\mathrm{~A})$, a decrease in yeast viability was observed,

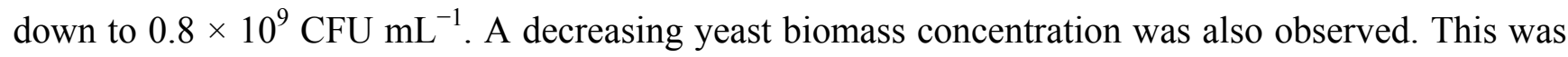
caused by a lack of cell growth, and because of sampling, since biomass was collected several times during the cultivation.

Even at a yeast biomass concentration of $60 \mathrm{~g} \mathrm{~L}^{-1}$ during the first $24 \mathrm{~h}$ there were residual sugars left in the permeate. The level of residual sugars decreased to almost zero, as the yeast biomass concentration increased along the cultivation. However, when $21.8 \mathrm{~g} \mathrm{~L}^{-1}$ (A) furfural was injected the residual sugar concentration drastically increased to $11 \mathrm{~g} \mathrm{~L}^{-1}$ (Figure 2).

Figure 3. Yeast viability and biomass dry weight at different furfural additions in anaerobic continuous cultivations on sucrose. Triangular symbols denote pulse injection experiments, viability measured $4 \mathrm{~h}$ after furfural injection. Square symbols denote experiments with continuous furfural addition, viability measured after $24 \mathrm{~h}$ continuous addition of furfural at the indicated concentrations. Closed and open symbols denote cultivation $\mathrm{A}$ and $\mathrm{B}$, respectively.
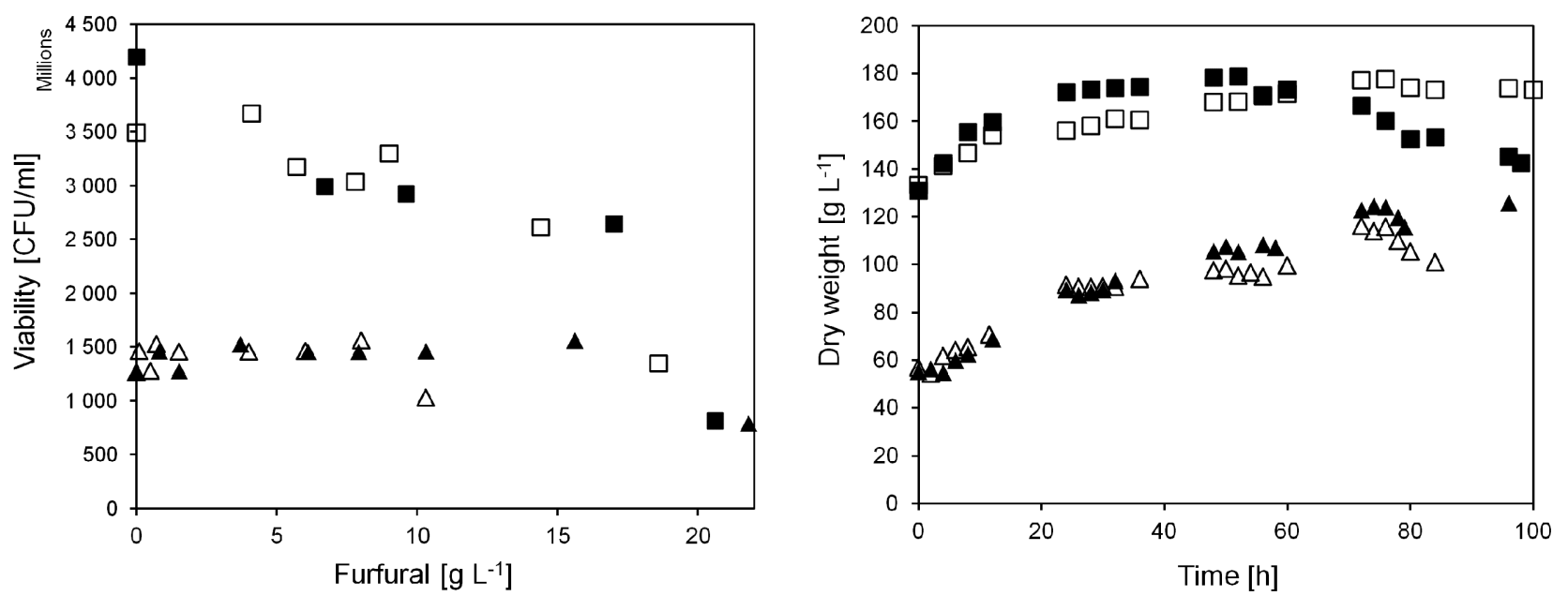

\subsection{Anaerobic Continuous Cultivations with Furfural Containing Inlet Medium}

The result from the continuous cultivation with furfural addition to the medium is summarized in Figure 4 and Table 1. In this experiment, more residual sugars were left unfermented in the spent liquid in contrast to when furfural pulse injections were performed. The level of sucrose increased during the entire cultivation (A) from 2 to $11 \mathrm{~g} \mathrm{~L}^{-1}$. The glucose concentration stayed below $2 \mathrm{~g} \mathrm{~L}^{-1}$ during the first $72 \mathrm{~h}$, but increased to $29 \mathrm{~g} \mathrm{~L}^{-1}$ after adding $20.6 \mathrm{~g} \mathrm{~L}^{-1}$ furfural to the cultivation for $24 \mathrm{~h}$. The same trends were seen in cultivation B.

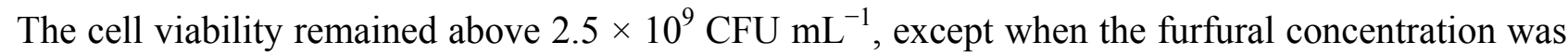
increased to either 18.6 (B) or 20.6 (A) $\mathrm{g} \mathrm{L}^{-1}$ in the feed (Figure 3). After feeding 18.6 or $20.6 \mathrm{~g} \mathrm{~L}^{-1}$ furfural for $24 \mathrm{~h}$, the cell viability had decreased by $52 \%$ or $68 \%$ to only $1.35 \times 10^{9}$ or $0.8 \times 10^{9} \mathrm{CFU} \mathrm{mL} \mathrm{mL}^{-1}$. During this time, an increasing amount of furfural in the spent liquid was observed, indicating that the inflow of furfural was higher than the yeasts' in situ detoxification capacity for 
furfural. Throughout most of the cultivation, the furfural level in the spent medium was less than $0.5 \mathrm{~g}$ $\mathrm{L}^{-1}$. When the concentration of furfural was increased to 18.6 (B) or 20.6 (A) $\mathrm{g} \mathrm{L}^{-1}$, the outflow of the bioreactor contained a rising concentration of furfural. Apparently, the yeast could convert almost all furfural as long as the amount of furfural did not exceed a certain level.

At a constant furfural addition of $6.7,9.6$ and $17 \mathrm{~g} \mathrm{~L}^{-1}(\mathrm{~A})$ or $4.1,5.7,7.8$, and $9.0 \mathrm{~g} \mathrm{~L}^{-1}$ (B) the ethanol concentration remained stable. When adding 18.6 (B) or 20.6 (A) $\mathrm{g} \mathrm{L}^{-1}$ furfural the conversion capacity of the yeast was not high enough and the furfural concentration reached a critical level which made the yeast unable to maintain a stable ethanol production. During the following hours from 72 to $98 \mathrm{~h}$ (A) the ethanol concentration in the bioreactor decreased from 50 to $11 \mathrm{~g} \mathrm{~L}^{-1}$.

Figure 4. Concentrations of sucrose, glucose, ethanol, glycerol and furfural during two anaerobic continuous cultivations with continuous furfural addition (A and $\mathrm{B}$ ). The furfural concentration $\left(\mathrm{g} \mathrm{L}^{-1}\right)$ in the inlet medium and the permeate during each cultivation day is shown in the lower graphs. After each $24 \mathrm{~h}$ period, denoted by the gray gridlines in the graphs, the furfural concentration in the inlet medium was increased to the indicated concentration.
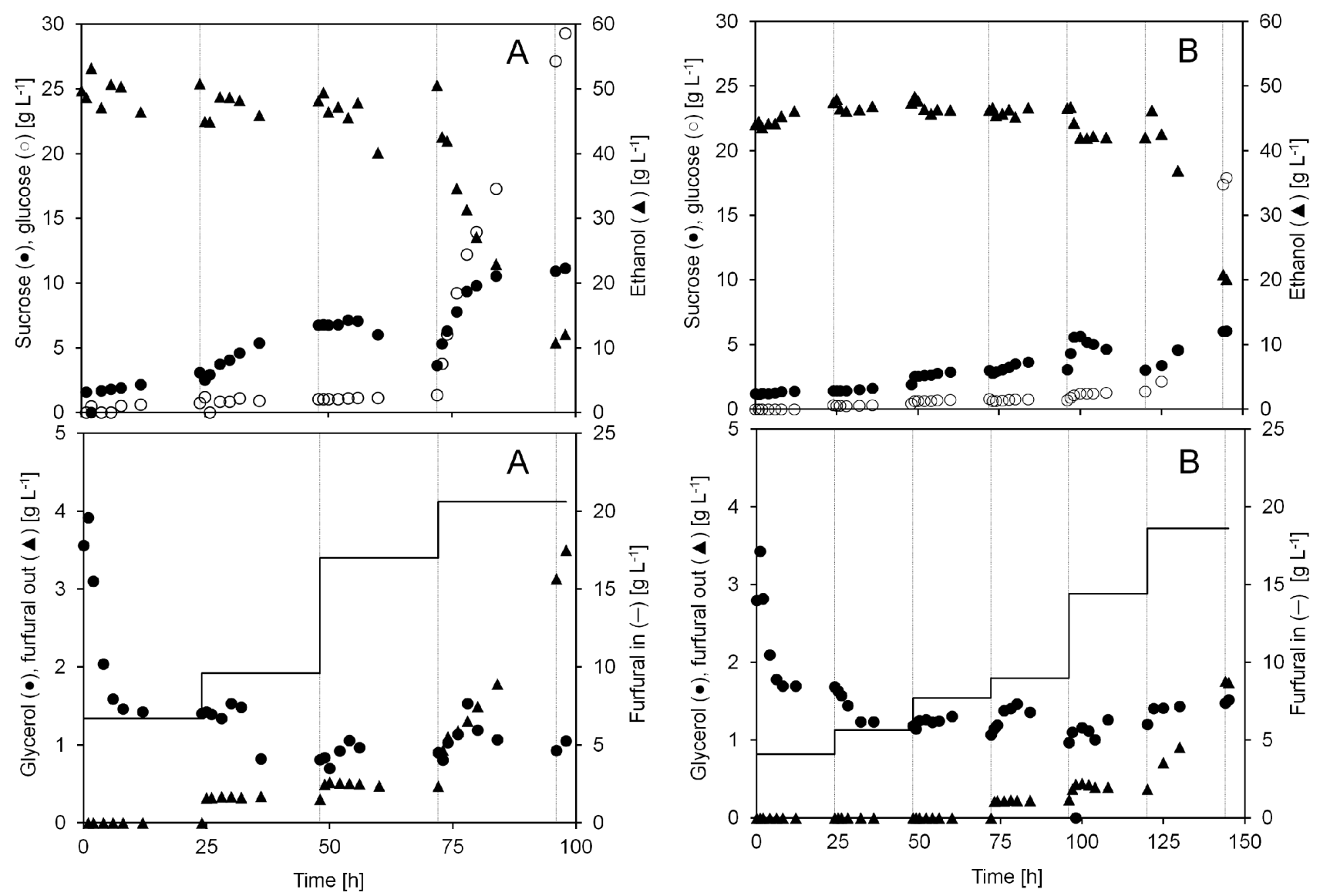

The maximal cell concentration reached was $180 \mathrm{~g} \mathrm{~L}^{-1}$, although, after $72 \mathrm{~h}$ when adding $17.0 \mathrm{~g} \mathrm{~L}^{-1}$ (A) furfural into the cultivation this value started to decline in cultivation A. The biomass amount inside the reactor decreased not only due to biomass sampling and lack of cell growth but also because of reduced cell size and/or cell lysis. Interestingly, the concentration of glycerol in the broth was below $2 \mathrm{~g} \mathrm{~L}^{-1}$ except during the first $4 \mathrm{~h}$. This is probably due to the same effect discussed above, since furfural 
conversion prevents the formation of glycerol. However, glycerol production never stopped entirely, glycerol was always present at low levels in the broth. At an inlet furfural concentrations of $18.6 \mathrm{~g} / \mathrm{L}$ or higher, the furfural concentrations in the reactor became inhibitory. The increased stress under such conditions may very well lead to increased glycerol yield as part of the general stress response. Hypothetically, the increased sugar concentrations and the very high cell density may have triggered responses to osmotic stress, something which is well known to induce glycerol production [24].

\subsection{Cell Retention and Furfural Conversion}

When furfural is added to high broth concentrations, the yeast growth is strongly inhibited and this may lead to washout in a traditional continuous cultivation without cell retention [7]. However, when a membrane filtration unit is used for total cell retention, washout will not occur even if the cells are not growing, since all cells are kept inside the bioreactor by the membranes even at a dilution rate of $0.5 \mathrm{~h}^{-1}$. This gives good advantages since the cells do not have to grow to be retained inside the bioreactor. The combination of eliminated washout and high cell concentrations makes cell retention methods especially suitable for fermentation of sugars at high dilution rates and higher productivity [17]. Immobilizing the yeast has also been proven as a successful method for fermenting toxic media, e.g., lignocellulosic hydrolyzate, at higher dilution rates of $0.3-0.5 \mathrm{~h}^{-1}[25,26]$. However, several practical problems with immobilization exist, which make immobilization complicated to use at industrial scale.

It has been confirmed [7,27,28] that the NADH-dependent enzyme alcohol dehydrogenase, which catalyzes the reduction of acetaldehyde to ethanol, additionally converts furfural to furfuryl alcohol under anaerobic conditions. This metabolic biotransformation is referred to as in situ detoxification since a less toxic product is created in the conversion. Since the same enzyme is used both for acetaldehyde as for furfural conversion, the production rate of ethanol and ATP would be lowered if the enzyme capacity becomes limiting. Reduced energy supply in the cells can cause, e.g., reduced biomass production. This would explain why batch cultivations with added furfural result in reduced biomass yield, lowered specific growth rate and ethanol productivity $[6,8,29]$.

A prerequisite to maintain the cells' ability to perform in situ detoxification is to select a suitable operation mode for the cultivation. During continuous and fed-batch cultivations, S. cerevisiae is more tolerant to furfural, because high concentrations of inhibitors can be avoided in the cultivation broth if the feeding rate is appropriate. In a continuous cultivation without yeast retention no negative effects on either ethanol or biomass yield appeared at a dilution rate of $0.315 \mathrm{~h}^{-1}$ with $2.0 \mathrm{~g} \mathrm{~L}^{-1}$ furfural in the inlet medium, while $4.3 \mathrm{~g} \mathrm{~L}^{-1}$ furfural resulted in washout [7]. However, in this study, the yeast successfully produced $\sim 47 \mathrm{~g} \mathrm{~L}^{-1}$ ethanol at an inlet medium level of $17.0 \mathrm{~g} \mathrm{~L}^{-1}$ furfural at a dilution rate of $0.5 \mathrm{~h}^{-1}$.

\subsection{Kinetics of Furfural Conversion}

Michaelis-Menten saturation kinetics was used in order to describe the specific furfural conversion rate based on results from the pulse injection or continuous furfural addition experiments in MATLAB $^{\circledR}$. The maximum specific conversion rate of furfural $\left(q_{\max }\right)$ and the Michaelis-Menten constant $\left(\mathrm{K}_{\mathrm{m}}\right)$ for furfural pulse injections was determined as $\mathrm{q}_{\max }=0.41 \mathrm{~g} \mathrm{~L}^{-1} \mathrm{~h}^{-1}$ and $\mathrm{K}_{\mathrm{m}}=3.1 \mathrm{~g} \mathrm{~L}^{-1}$ (Figure 5), in the same way as earlier described by Sárvári Horváth et al. [7]. The estimated specific 
furfural conversion rate was $0.35 \mathrm{~g} \mathrm{~g}^{-1} \mathrm{~h}^{-1}$ within 15 min after pulse injection of $21.8 \mathrm{~g} \mathrm{~L}^{-1}$ furfural to the cultivation. When less than $3.7 \mathrm{~g} \mathrm{~L}^{-1}$ furfural was added, the conversion rate could not be calculated as all furfural had been converted in less than $15 \mathrm{~min}$.

The calculated $\mathrm{q}_{\max }$ of $0.41 \mathrm{~g} \mathrm{~L}^{-1} \mathrm{~h}^{-1}$ during furfural pulse injections was lower than previously reported maximum rates. However, unlike previous investigations the yeast in the present study was cultivated at high cell density, the yeast grew slowly and behaved more like stationary phase cells. In previous studies, furfural was pulsed either to exponentially growing yeast in batch cultivations [8] or into ordinary chemostat cultures at steady-state, without cell retention [7]. Sárvári Horváth et al. [7] presented a maximum specific furfural conversion rate of around $0.6 \mathrm{~g} \mathrm{~g}^{-1} \mathrm{~h}^{-1}$, determined during pulse addition of furfural for yeast growing in anaerobic conditions at a dilution rate of $0.10 \mathrm{~h}^{-1}$.

Michaelis-Menten saturation kinetics was fitted also to the observed specific furfural conversion rates and steady state furfural concentrations obtained at different feed concentrations of furfural. In this case, the fitted $\mathrm{q}_{\max }$ was $0.07 \mathrm{~g} \mathrm{~L}^{-1}$ and $\mathrm{K}_{\mathrm{m}}$ was $0.25 \mathrm{~g} \mathrm{~L}^{-1} \mathrm{~h}^{-1}$ (Figure 5). The results of the furfural conversion during continuous furfural addition thereby showed completely different saturation kinetics compared to the pulse injections experiments. Without cell retention, Sárvári Horváth et al. [7] showed that the specific conversion rate of furfural increases with increasing dilution rate until washout with a maximum value of $0.15 \mathrm{~g} \mathrm{~g}^{-1} \mathrm{~h}^{-1}$. Thus, growing yeast appears to convert furfural at faster specific rates compared to the slow growing cells in the membrane bioreactor. However, unlike in the Sárvári Horváth et al. study, washout could not occur in our experiment and a much faster total volumetric furfural conversion rate could be reached due to the high cell density.

Figure 5. Summary of the specific conversion rate of furfural $\left(\mathrm{q}_{\mathrm{F}}\right)$ in cultivations with pulse injection (left) or continuous (right) furfural addition. The $\mathrm{q}_{\mathrm{F}}$ values for two separate cultivations are presented together with the regression curve calculated based on Michaelis-Menten kinetics. Open/closed symbols denote separate experiments.
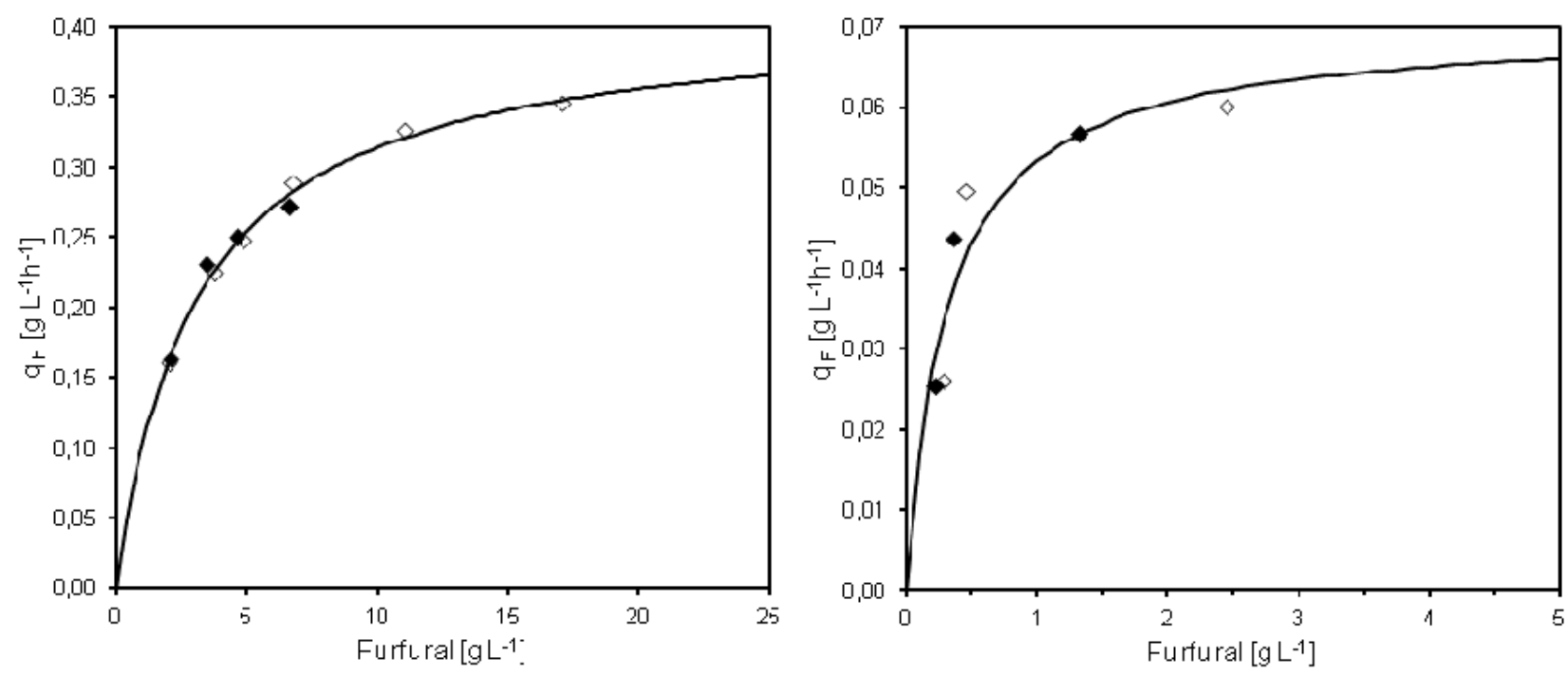

Interestingly, furfural seems to not have a direct toxic effect on the cells, since the cells recovered even when over $15 \mathrm{~g} \mathrm{~L}^{-1}$ was pulsed into the cultivation. The cells could also survive several days with constant addition of furfural, although the cell growth was affected negatively at a furfural 
concentration over $10 \mathrm{~g} \mathrm{~L}^{-1}$. A previous study on the proteomic response of $S$. cerevisiae to furfural addition revealed that the expressions of most proteins did not change $20 \mathrm{~min}$ after furfural pulse injection [30]. However, after 2 h, 50 proteins demonstrated up or downregulation. On the other hand, pulse addition of furfural has been shown to induce a large transcriptome change in $S$. cerevisiae within 20 minutes [31]. For example, genes controlling transcription and translation are downregulated which will affect cell growth. Several stress response genes, encoding mitochondrial proteins, are also upregulated [31]. These observations indicate, that when furfural is continuously added to the cultures, there is probably a transcriptional response which affects the furfural-converting enzymes, while during the pulse injections, no major changes occur before the added furfural is consumed. This can explain why two different furfural conversion kinetics were observed in our study depending on if furfural was pulse injected or fed continuously to the cultivation.

\section{Conclusions}

The results of this work confirm that it is possible to use the inherent capacity of $S$. cerevisiae for in situ detoxification of feed medium containing furfural with up to $17.0 \mathrm{~g} \mathrm{~L}^{-1}$, and at the same time still produce ethanol rapidly at $23 \mathrm{~g} \mathrm{~L}^{-1} \mathrm{~h}^{-1}$. Continuous cultivations were successfully conducted on sucrose medium at a rapid dilution rate of $0.5 \mathrm{~h}^{-1}$ using a membrane module for complete cell retention. The biomass concentration inside the bioreactor could thereby be increased to $180 \mathrm{~g} \mathrm{~L}^{-1}$. Pulse injection of furfural also showed that the yeast could rapidly convert the furfural even at $21.8 \mathrm{~g} \mathrm{~L}^{-1}$ furfural. Furfural addition did not influence the yeast viability significantly as long as no more than $17 \mathrm{~g} \mathrm{~L}^{-1}$ was added with the inlet medium. It was also noted that during furfural conversion, glycerol production decreased significantly. The results show that keeping high biomass levels in the bioreactor has potential when it comes to simultaneous detoxification of toxic medium and ethanol production during continuous cultivations at high dilution rates.

\section{Acknowledgments}

This work was financially supported by the Swedish Energy Agency and Swedish Research Council.

\section{References}

1. Galbe, M.; Zacchi, G. A review of the production of ethanol from softwood. Appl. Microbiol. Biotechnol. 2002, 59, 618-628.

2. Taherzadeh, M.J.; Karimi, K. Acid-based hydrolysis processes for ethanol from lignocellulosic materials: A review. BioResources 2007, 2, 472-499.

3. Larsson, S.; Palmqvist, E.; Hahn-Hägerdal, B.; Tengborg, C.; Stenberg, K.; Zacchi, G.; Nilvebrant, N.-O. The generation of fermentation inhibitors during dilute acid hydrolysis of softwood. Enzyme Microb. Technol. 1999, 24, 151-159.

4. Olsson, L.; Hahn-Hägerdal, B. Fermentation of lignocellulosic hydrolysates for ethanol production. Enzyme Microb. Technol. 1996, 18, 312-331. 
5. Chandel, A.K.; Silvério da Silva, S.; Singh, O.V. Detoxification of Lignocellulosic Hydrolysates for Improved Bioethanol Production In Biofuel Production-Recent Developments and Prospects; Aurélio dos Santos Bernardes, M., Ed.; InTech: Rijeka, Croatia, 2011.

6. Azhar, A.F.; Bery, M.K.; Colcord, A.R.; Roberts, R.S.; Corbitt, G.V. Factors affecting alcohol fermentation of wood acid hydrolysate. Biotechnol. Bioeng. Symp. 1981, 11, 293-300.

7. Sárvári Horváth, I.; Taherzadeh, M.J.; Niklasson, C.; Lidén, G. Effects of furfural on anaerobic continuous cultivation of Saccharomyces cerevisiae. Biotechnol. Bioeng. 2001, 75, 540-549.

8. Taherzadeh, M.J.; Gustafsson, L.; Niklasson, C.; Lidén, G. Conversion of furfural in aerobic and anaerobic batch fermentation of glucose by Saccharomyces cerevisiae. J. Biosci. Bioeng. 1999, 87, 169-174.

9. Palmqvist, E.; Almeida, J.S.; Hahn-Hägerdal, B. Influence of furfural on anaerobic glycolytic kinetics of Saccharomyces cerevisiae in batch culture. Biotechnol. Bioeng. 1999, 62, 447-454.

10. Taherzadeh, M.J.; Eklund, R.; Gustafsson, L.; Niklasson, C.; Lidén, G. Characterization and Fermentation of Dilute-Acid Hydrolyzates from Wood. Ind. Eng. Chem. Res. 1997, 36, 4659-4665.

11. Nilsson, A.; Taherzadeh, M.J.; Lidén, G. Use of dynamic step response for control of fed-batch conversion of lignocellulosic hydrolyzates to ethanol. J. Biotechnol. 2001, 89, 41-53.

12. Brandberg, T.; Karimi, K.; Taherzadeh, M.J.; Franzén, C.J.; Gustafsson, L. Continuous fermentation of wheat-supplemented lignocellulose hydrolysate with different types of cell retention. Biotechnol. Bioeng. 2007, 98, 80-90.

13. Chung, I.S.; Lee, Y.Y. Ethanol fermentation of crude acid hydrolyzate of cellulose using high-level yeast inocula. Biotechnol. Bioeng. 1985, 27, 308-315.

14. Palmqvist, E.; Hahn-Hägerdal, B. Fermentation of lignocellulosic hydrolysates. II: inhibitors and mechanisms of inhibition. Bioresour. Technol. 2000, 74, 25-33.

15. Taherzadeh, M.J.; Niklasson, C.; Lidén, G. Conversion of dilute-acid hydrolyzates of spruce and birch to ethanol by fed-batch fermentation. Bioresour. Technol. 1999, 69, 59-66.

16. Judd, S.; Judd, C. The MBR Book, Principles and Applications of Membrane Bioreactors for Water and Wastewater Treatment, 2nd ed.; Butterworth-Heinemann: Oxford, UK, 2011.

17. Lafforgue, C.; Malinowski, J.; Goma, G. High yeast concentration in continuous fermentation with cell recycle obtained by tangential microfiltration. Biotechnol. Lett. 1987, 9, 347-352.

18. Lee, C.W.; Chang, H.N. Kinetics of ethanol fermentations in membrane cell recycle fermentors. Biotechnol. Bioeng. 1987, 29, 1105-1112.

19. Ben Chaabane, F.; Aldiguier, A.S.; Alfenore, S.; Cameleyre, X.; Blanc, P.; Bideaux, C.; Guillouet, S.E.; Roux, G.; Molina-Jouve, C. Very high ethanol productivity in an innovative continuous two-stage bioreactor with cell recycle. Bioprocess Biosyst. Eng. 2006, 29, 49-57.

20. Sur, H.W.; Cui, Z. Experimental study on the enhancement of yeast microfiltration with gas sparging. J. Chem. Technol. Biotechnol. 2001, 76, 477-484.

21. Starbard, N. Beverage Industry Microfiltration; Wiley-Blackwell: Ames, IA, USA, 2008.

22. Patel, P.N.; Mehaia, M.A.; Cheryan, M. Cross-flow membrane filtration of yeast suspensions. J. Biotechnol. 1987, 5, 1-16.

23. Gehlert, G.; Luque, S.; Belfort, G. Comparison of Ultra- and Microfiltration in the Presence and Absence of Secondary Flow with Polysaccharides, Proteins, and Yeast Suspensions. Biotechnol. Prog. 1998, 14, 931-942. 
24. Hohmann, S. Osmotic Stress Signaling and Osmoadaptation in Yeast. Microbiol. Mol. Biol. Rev. 2002, 66, 300-372.

25. Talebnia, F.; Taherzadeh, M.J. In situ detoxification and continuous cultivation of dilute-acid hydrolyzate to ethanol by encapsulated $S$. cerevisiae. J. Biotechnol. 2006, 125, 377-384.

26. Taherzadeh, M.J.; Millati, R.; Niklasson, C. Continuous cultivation of dilute-acid hydrolysates to ethanol by immobilized Saccharomyces cerevisiae. Appl. Biochem. Biotechnol. 2001, 95, 45-57.

27. Modig, T.; Lidén, G.; Taherzadeh, M.J. Inhibition effects of furfural on alcohol dehydrogenase, aldehyde dehydrogenase and pyruvate dehydrogenase. Biochem. J. 2002, 363, 769-776.

28. Diaz De Villegas, M.E.; Villa, P.; Guerra, M.; Rodriguez, E.; Redondo, D.; Martinez, A. Conversion of furfural into furfuryl alcohol by Saccharomyces cervisiae 354. Acta Biotechnol. 1992, 12, 351-354.

29. Boyer, L.J.; Vega, J.L.; Klasson, K.T.; Clausen, E.C.; Gaddy, J.L. The effects of furfural on ethanol production by Saccharomyces cerevisiae in batch culture. Biomass Bioenergy 1992, 3, $41-48$.

30. Lin, F.-M.; Tan, Y.; Yuan, Y.-J. Temporal quantitative proteomics of Saccharomyces cerevisiae in response to a nonlethal concentration of furfural. Proteomics 2009, 9, 5471-5483.

31. Li, B.-Z.; Yuan, Y.-J. Transcriptome shifts in response to furfural and acetic acid in Saccharomyces cerevisiae. Appl. Microbiol. Biotechnol. 2010, 86, 1915-1924.

(C) 2013 by the authors; licensee MDPI, Basel, Switzerland. This article is an open access article distributed under the terms and conditions of the Creative Commons Attribution license (http://creativecommons.org/licenses/by/3.0/). 